\title{
THE ROLE OF CREATIVITY IN ENTREPRENEURSHIP
}

\author{
Maria Irina Dromereschi \\ Technical College “Anghel Saligny” Bacau \\ Dromereschi_irina@yahoo.com
}

\begin{abstract}
One of the most important factors to explain the sudden relevance of entrepreneurship, was the importance of creativity as a new source of competitiveness. Psychologists argue that being creative means to create something new, original and appropriate reality. Creative is characterized by originality and expressiveness, is imaginative, generative, pathfinder, invention, innovation etc. Increasing effects of globalization leads to the need creative approach in a market with a high level of opportunity and competition. Entrepreneurial factors overlap with many creative features such as curiosity, self-confidence, a high level of energy, responsibility and vision. As a highly complex mental formation, creativity is characterized by a multitude of ways such as productivity, usability, efficiency, value, ingenuity, innovation and originality. The impact of entrepreneurial creativity extends to the whole life of an entrepreneur, and not just during business. Success is stimulated by the use of juxtaposition and combination of different ideas that often but not related to the impact on decision making. Entrepreneurial Creativity should be seen as a competitive force and portfolio of skills. Adopting a creative entrepreneurial approach protects us from uncertainty and ambiguity in decision making in the external environment.
\end{abstract}

\section{Keywords}

creativity; entrepreneurship; entrepreneurship creativity; entrepreneurial society

\section{JEL Classification}

L21; L26

\section{Introduction}

Force entrepreneurship is vital for economic growth and provides many social opportunities. Entrepreneurial capital investments, such as schools, culture and other institutions to develop entrepreneurial creativity are needed not only to form a "stock" of aspiring entrepreneurs but also in the long term, to maintain leadership in the global economy. When organizations exist to serve the people, the business is striving emotional, vital, innovative, creative entrepreneurs who own welfare maximizing its showcase its full potential human selfless service to others. Theory of Knowledge excess entrepreneurship (Audretsch, 2007) suggests that those environments that are rich in knowledge will tend to generate more business opportunities. Less entrepreneurial opportunities will generate a context with a smaller amount of investment in new ideas and knowledge. A consequence of globalization, which changed the comparative advantage of developed countries in physical capital in knowledge capital are becoming entrepreneurial opportunities ubiquitous (Audretsch, 2007).

\section{Entrepreneurship and creativity - conceptual approach}

Moving from knowledge to activities based on creativity, innovation, entrepreneurship and imagination was perceived as a substantial change in the 
perception of the economy last decade (Van Oke et al, 2009). Increasing effects of globalization and the impact of technology led to the identification of a greater number of business opportunities, while the market was already a crowded place increased competition (McMullan JS et al, 2006). The difference seems to be time specific creativity tool that allows entrepreneurs to access opportunities in ways that can bring competitive advantage of the firm, company or his organization. This may provide the basis for innovation and business development, and a positive impact on society in general (Bilton, 2007). Entrepreneurship occurs in all types and sizes of organizations, from small business, corporate internal, to global. Entrepreneurship can be defined as the process of creating value for the business and social community by making unique combination of public and private resources exploiting economic opportunities, social or cultural in a changing environment. Creativity has been regarded as a construction of ideas or products that are new and potentially useful (Amabile, 1998), although in a sense of entrepreneurship should be a link-up between innovation and profitability translated into monetary and social. Creativity allows the organization to seize the opportunities that arise as a result of changing environmental conditions (Shalley CE et al, 2004). Entrepreneurship Schumpeterian vision has three central dimensions: innovation, risk taking and proactiveness. Innovation is the manner in which the contractor seeks new opportunities, and how ideas are brought to a conclusion profitable. Test innovation success is measured rather than market ideas in an actual news. Risk-taking refers to the way in which innovation is embedded in, and by the organization, company or community. It also refers to people's willingness to allocate significant resources to opportunities, resources calculated to succeed. Proactive behavior is concern, the determination to make things happen, adaptability and breaking rules determined to do things. Creativity involves a perceptual response to the environment, which in turn can induce a greater or lesser frequency of creative effort. The term "creative intensity" is used by Morris and his colleagues (2003) to illustrate the combined effects of the degree and frequency of creative behavior at the individual, organization or company. Individual creativity within an organization enhances global competitive advantage and organizational innovation, while creative teams or groups of people make it possible to further increase this advantage (Hirst et al, 2009). There is no universally accepted definition of creativity, although there is some overlap in its interpretation. Creativity is human specific and can be defined as a predisposition to generate and promote new in all its forms because it is innate but equally to everyone. Creativity is the basis of innovation, which in turn, the engine of progress and the most important factor of competitiveness. Innovation is also a defining characteristic of entrepreneurship. Creativity educates and more, can be stimulated, in particular through group techniques. Superior intelligence is useful creativity, but above a certain threshold inhibits creativity. Characteristic of creativity is that excels in identifying problems compared with troubleshooting. A preliminary analysis identifies creativity with imagination and originality of thought moving beyond the ordinary. It can be characterized by overcoming conventional or even breaking the rules. Young (1985) defines creativity as a natural tendency to actualize our potential, which involves integration with the intuitive logic. This may involve both an advance in thinking, but it can also keep links with the past. Ford and Harris (1992) believe it to be a deliberate process and are modifiable to some extent throughout the world. Hunter (2007) sees creativity as a result of interaction between the individual and the situation after some appropriate environment or climate. Creativity occurs best when exploring routes are flexible, non-predetermined and discovery is possible (Amabile, 1983). Fillis and Rentschler (2006) found that creative solutions need not be complex, especially in business relative to the situation where answers are able to bring success to the organization. 


\section{Connections between creativity and entrepreneurship}

Connections between creativity and entrepreneurship were made by Whiting (1988) and Lee (2004). In 1974, Stein argued about creative ability and entrepreneurial capacity building that are separate, so challenged in 1984 by Gilad. Whiting (1988) identified independence, the desire to achieve, curiosity, self-confidence and deep involvement in a task that five main characteristics of creative individuals as selfconfidence, perseverance, a high level of energy, risk-taking calculated and the need to have been regarded as the top five characteristics of individual entrepreneurship. Other relevant factors include the use of initiative and flexibility. The existence of differences between being creative and being an entrepreneur does not exclude duplication. In 2007 Fillis observed stability factors creative entrepreneurs over time. Entrepreneurship is seen as an important contributor to economic growth and job creation while understanding the impact on the process of creativity is crucial (Baumol, 2002).

\section{Entrepreneurial Creativity}

Entrepreneurial Creativity was defined as the generation and implementation of new (Amabile, 1997). Entrepreneurial Creativity is a continuous process: there before, during and lifetime of a business, it is a result of social context and individual decision (Fillis I \& Rentschler R, 2006). Entrepreneurial Creativity requires a combination of intrinsic motivation and extrinsic motivation certain - a motivational synergy that results when strong levels of personal interest and involvement combined promise of rewards: confirmation of competence, support for skills development and achievement in the future (Amabile, 1997). Those organizations that are prepared to recognize creative accomplishments are then likely to encourage creative behavior. A model driving style democracy and participation facilitates creativity (Nystrom, 1979). And the vision of a leader is an important factor in managing creative people (Becherer R.C. et al, 2008). This vision must be communicated through informal and formal channels appropriate and at all levels of management. An organizational culture that facilitates risk-taking is also able to enhance the creative achievements. Individual or team creativity is often at the root of innovation. Akehurst (2009) believes that, instead of focusing on individual talent, organization leaders should be more concerned with creating and sustaining a domestic environment supportive of collective support for creativity and innovation. Entrepreneurship bottom up, where creative thinking and innovative behavior by the employer, was referred to as intrapreneurship (Huse $\mathrm{M}$ et al, 2005). Therefore, an entrepreneurial culture can have a positive effect on the climate of creation. Mumford (2002) and Amabile (2004) found that leader support was positively related to the level of creativity of employees. Therefore, it can be assumed that an entrepreneurial culture is more likely to result in support of leader as an entrepreneur than other forms of management, employee empowerment through decision making.

\section{Entrepreneurial creativity - European perspective}

Entrepreneurship is manifested in the economy as a multiplicity and variety of forms, with very different results not only reflects the economic welfare and financial. Similarly, entrepreneurship is correlated with technological development, job creation and reducing social inequities or issue of environment. The process of globalization and the global crisis of recent years have favored a series of structural changes deeply felt in the business plan. A pressure increased competitiveness enterprise, which resulted in an increase in productivity by using the new technologies and process innovation. In addition, developments in information and communication technology have led to creating new markets, which have revolutionized production processes in 
many economic sectors: industry and, in particular, the service sector. Advanced technology and low cost transmission remote data have helped to facilitate entrepreneurs' access to knowledge and networks cooperation, enabling them to operate internationally. New opportunities have stimulated entrepreneurship and creativity, which are considered as engines of economic development 2020. In Europe, are created annually 4.1 million jobs only business start-ups. Entrepreneurial policies are more closely correlated with innovation, geared at creating new products and services by exploiting both meanings of the knowledge economy. "Europe 2020" is the European Union's strategy for growth, with the time horizon of 2020. In a rapidly changing world, the EU wants to become a smart, sustainable and inclusive growth. Smart growth concerns an economy based on knowledge and innovation. Sustainable development requires competitiveness and efficiency in resource use. Inclusive growth relates to a higher rate of employment in the economy, generating economic, social and territorial cohesion in the EU. These three priorities are mutually supportive and are able to help the EU and Member States to achieve a higher level of employment of labor productivity and territorial cohesion. In fact, five major goals are set on employment, innovation, education, social inclusion and the environment to be achieved by 2020. A number of factors were identified as determinants for the development of entrepreneurship. They were grouped into six categories which contain a number of elements influencing entrepreneurship regulatory framework, market conditions, access to financing, creation and dissemination of knowledge, entrepreneurial skills, culture and innovation, creativity, education and entrepreneurship. Entrepreneurial creativity is manifested in five areas: personal development (achievement technology, creativity, entrepreneurial skills, people skills), enterprise (new business models, venture management, innovation management), opportunities (discovering opportunities, pursuing opportunities, moving with speed), customer (creating customer, winning customer, retaining customer) and competition (competitive advantage, competitive strategies, change management).The trends that will provide opportunities include: green trend, cleanenergy trend, organic-orientation trend, economic trend, social trend, health trend, and Web trend. The sources of new ideas are: consumers, existing products and services, distribution channels, (federal) government, research and development. Given that unemployment is a matter of concern in many world economies, entrepreneurship is seen as a viable solution. To stimulate the development of entrepreneurial activity, the first step to take is to understand the complexity of national ecosystems and their specific characteristics. The private sector can contribute significantly to the development of entrepreneurship by implementing quality programs: training sessions, events and competitions for entrepreneurs just starting out, mentoring programs and support for start-ups or information sessions about existing funding opportunities. Facilitating access to accelerators, incubators and co-working spaces is another very important point, along with further promotion of successful models and correct reasons for being an entrepreneur.

\section{References}

Akehurst, G., Comeche, J.M. and Galindo, M-A. (2009), "Job satisfaction and commitment in the entrepreneurial SME", Small Business Economics, Vol.32, pp.277-289.

Amabile, T. (1983), The Social Psychology of Creativity, New York, Springer Verlag. Amabile, T. (1997), "Entrepreneurial creativity through motivational synergy", Journal of Creative Behavior, Vol.31, No.1, pp.18-26.

Amabile, T. (1998), "How to kill creativity”, Harvard Business Review, Vol. 76, No. 5, pp.77-88. 
Amabile, T.M, Schatzell, E.A., Moneta, G.B. and Kramer, S.J. (2004), "Leader behaviours and the work environment for creativity: perceived leader support”, The Leadership Quarterly, Vol.15, pp.5-32.

Audretsch, David B.(2007), The Entrepreneurial Society, New York: Oxford University Press.

Audretsch, David B., Max Keilbach and Erik Lehmann (2006), Entrepreneurship and Economic Growth, New York: Oxford University Press.

Baumol, W. (2002), The Free Market Innovation Machine: Analysing the Growth Miracle of Capitalism, Princeton University Press, Princeton.

Becherer, R.C., Mendenhall, M.E. and Eickhoff, K.F. (2008), "Separated at birth: an inquiry on the conceptual independence of the entrepreneurship and the leadership constructs”, New England Journal of Entrepreneurship, Vol.11, No.2, pp.13-27.

Bilton, C. (2007), Management and Creativity: From Creative Industries to Creative Management, Blackwell Publishing, Oxford.

Consultation on An Action Plan on Entrepreneurship, (2012), EU Commission, available at http://ec.europa.eu/enterprise/newsroom/cf/

Entrepreneurship 2020 Action Plan, available at http://ec.europa.eu/enterprise/ policies/sme/public-consultation/index_en.htm

Fillis, I. (2007a), 'A methodology for researching international entrepreneurship in SMEs: a challenge to the status quo', Journal of Small Business and Enterprise Development, Vol.14, No.1, pp.11 8-135.

Fillis, I. and Rentschler, R. (2006), Creative Marketing: An Extended Metaphor for Marketing in a New Age, Palgrave Macmillan, Basingstoke.

Ford, D.V. and Harris, J.J. (1992), "The elusive definition of creativity”, Journal of Creative Behavior, Vol. 26, No. 3, pp. 186-198.

Gilad, B. (1984), "Entrepreneurship: the use of creativity in the marketplace”, Journal of Creative Behavior, Vol.18, pp.1 51-161.

Hirst, G., Van Knippenberg, D. and Zhou, J. (2009), “A cross-level perspective on employee creativity: goal orientation, team learning behaviour and individual creativity", Academy of Management Journal, Vol.52, No.2, pp.280-293.

Hisrich, R.D., Peters, M.P, Sheperd, D.A.(2006), http://ebookdownload.cba.pl/ebook/free-entrepreneurship-8th-edition-robert-d-hisrichmichael-p-peters-dean-a-shepherd-ppt.html

Hunter, S.T., Bedell, K.E. and Mumford, M.D. (2007), "Climate for creativity: a quantitative review”, Creativity Research Journal, Vol.19, No.1, pp.69-90.

Huse, M., Neubaum, D.O. and Gabrielson, J. (2005), "Corporate innovation and competitive environment”, International Entrepreneurship and Management Journal, Vol.1, pp.313-333.

Lee, S.Y., Florida, R. and Acs, Z.J. (2004), "Creativity and entrepreneurship: a regional analysis of new firm formation”, Regional Studies, Vol.3 8, No.8, pp.879-891.

McMullan, J.S. and Shepherd, D.A. (2006), "Entrepreneurial action and the role of uncertainty in the theory of the entrepreneur", Academy of Management Review, Vol.31, No.1, pp.132-152.

Morris, M. H., Schindehutte, M. and LaForge, R. W. (2003), "The emergence of entrepreneurial marketing: nature and meaning" in Hills, G. E., Hansen, D. J., Solomon, G. T. and Winslow, E. K. Research at the Marketing/Entrepreneurship Interface, University of Illinois, Chicago.

Mumford, M.D., Scott, G.M, Gaddis, B. and Strange, J.M. (2002), "Leading creative people: orchestrating expertise and relationships", The Leadership Quarterly, Vol.13, pp.705-750.

Nystrom, H. (1979), Creativity and Innovation, John Wiley and Sons, Chichester. 
Shalley, C.E., Zhou, J. and Oldham, G.R. (2004), "The effects of personal and contextual characteristics on creativity: where should we go from here?”, Journal of Management, Vol.30, pp.933-958.

Van Oke, A., Munshi, N. and Walumbwa, F.O. (2009), “’'The influence of leadership on innovation processes and activities”, Organizational Dynamics, Vol.38, No.1, pp.64-72.

Whiting, B.G. (1988), “Creativity and entrepreneurship: how do they relate?”, Journal of Creative Behavior, Vol.22, pp.1 78-183.

Young, J.G. (1985). “What is creativity?”, Journal of Creative Behavior, Vol. 19, No. 2, pp. 77-87. 